
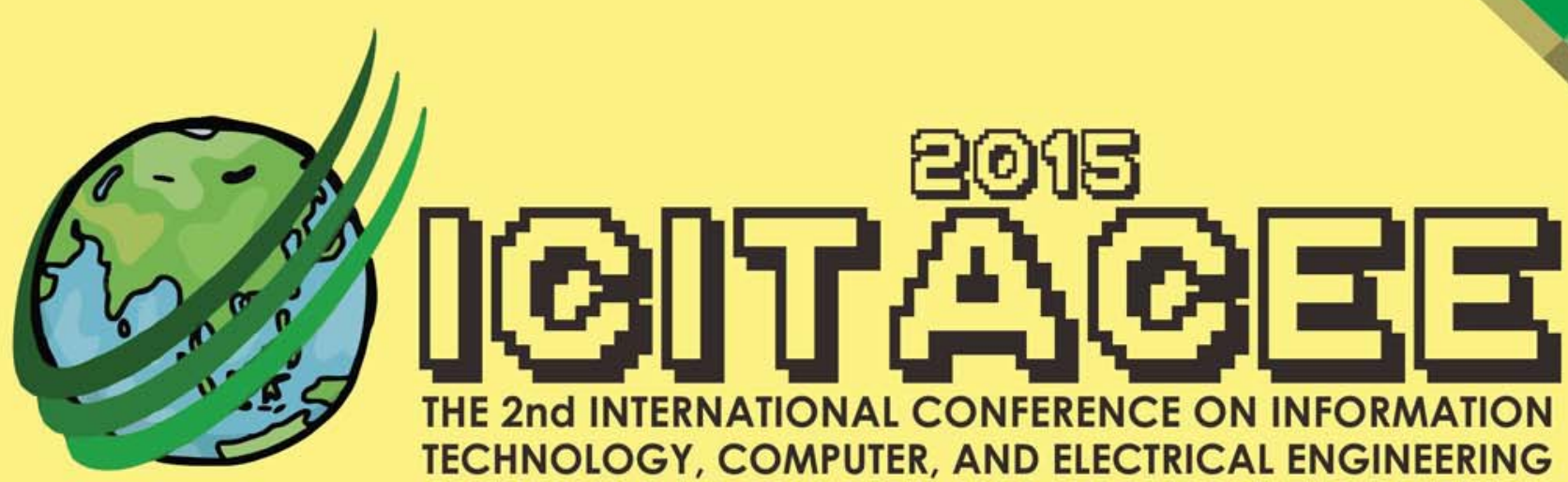

THE 2nd INTERNATIONAL CONFERENCE ON INFORMATION TECHNOLOGY, COMPUTER, AND ELECTRICAL ENGINEERING

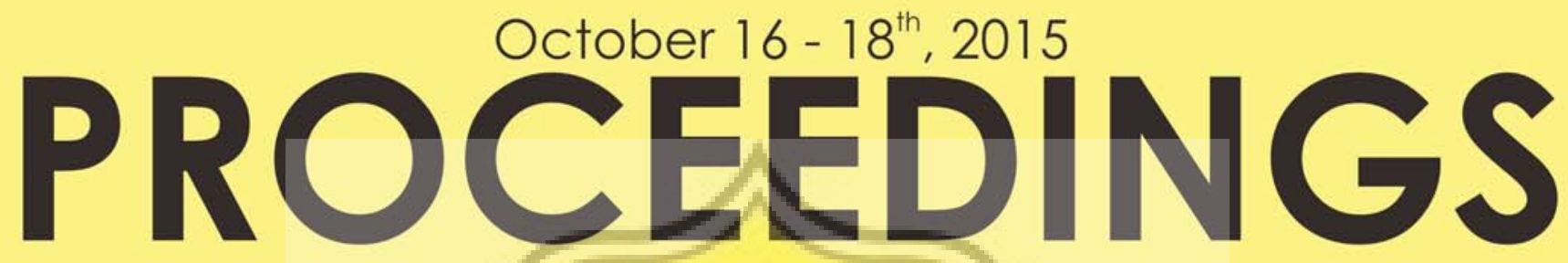

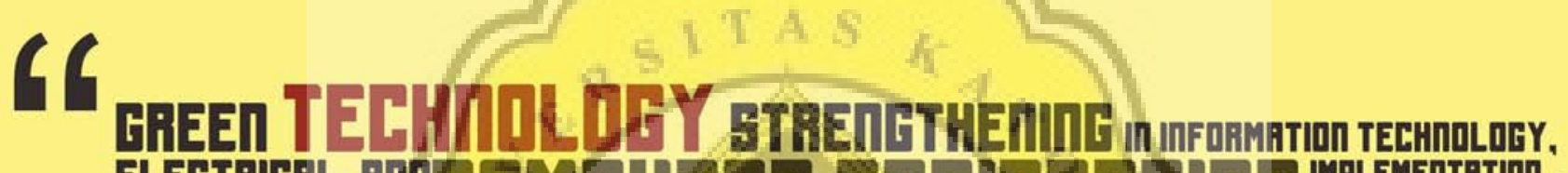

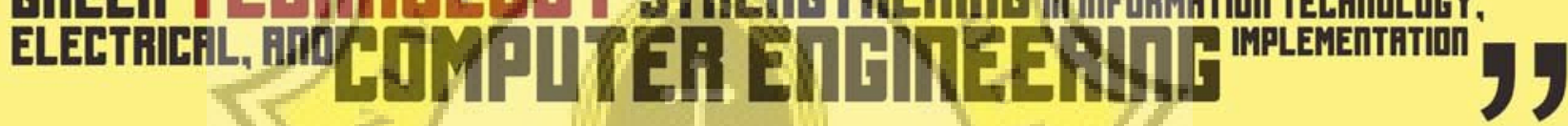

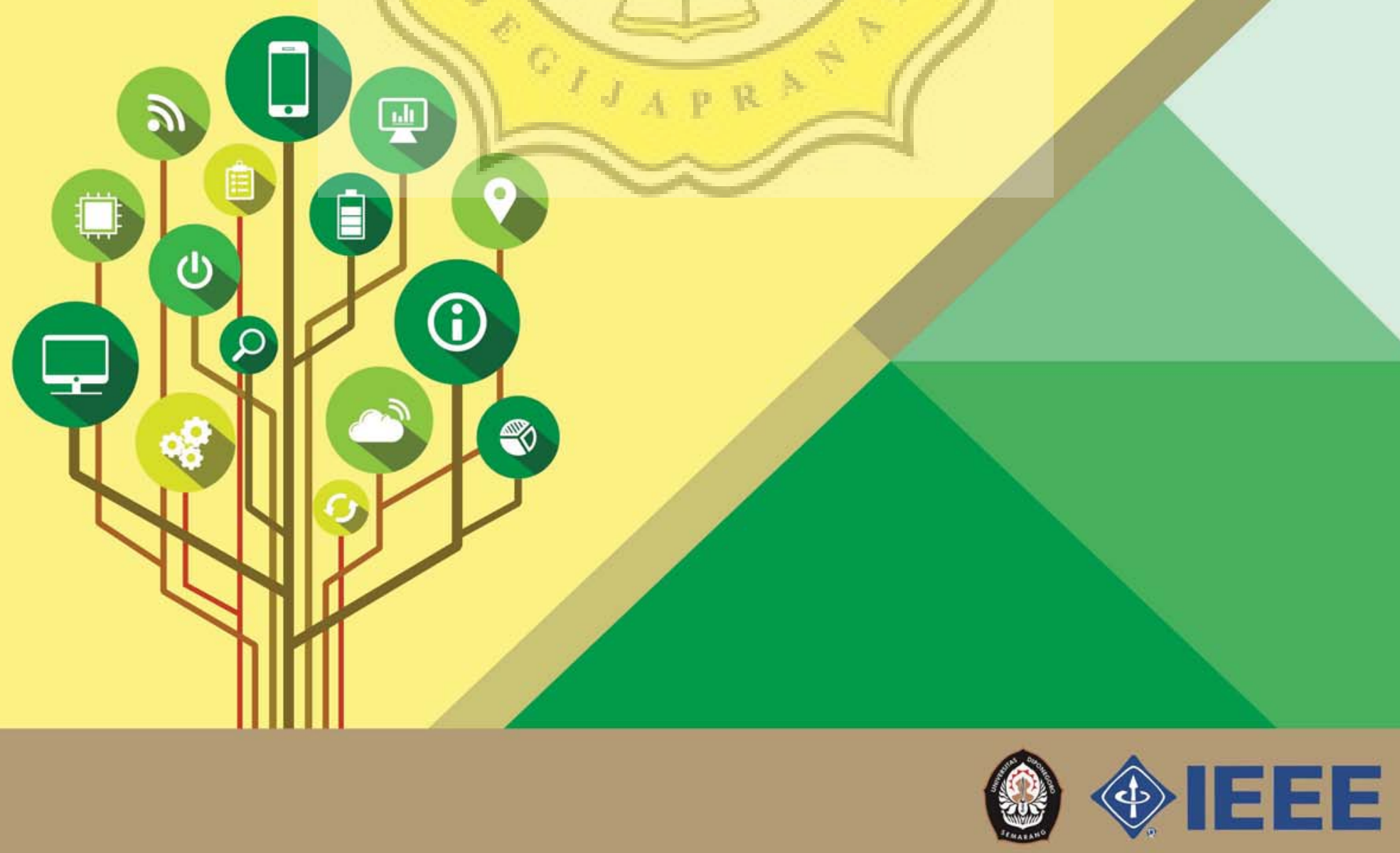




\section{Foreword from IEEE Indonesia Section Chair}

Dear colleagues, Professors, researchers, ICT professionals, ladies and gentlemen, good morning.

On behalf of IEEE Indonesia section, I would like to express my sincere gratitude and welcome you to the 2nd International Conference on Information Technology, Computer, and Electrical Engineering (ICITACEE 2015). The conference is an annual event, organized in collaboration between Computer Engineering Department and Electrical Engineering Department, Diponegoro University. In this year, the conference is organized by Computer Engineering Department, Diponegoro University, Semarang Indonesia.

ICITACEE 2015 with the theme Green Technology Strengthening in Information Technology, Electrical and Computer Engineering Implementation, has been approved and technically co-sponsored by IEEE Indonesia Section, with the conference No. \#36226. The previous conferences in 2014 were also technically cosponsored by the IEEE and successfully held in Semarang on 07 Nov 2014. The ICITACEE 2014 publication has been indexed by IEEE Xplore ${ }^{\circledR}$ Digital Library and Scopus.

As we may aware, IEEE is one of the largest professional associations in the world. Having been founded over 130 years ago, nowadays it brings together over 432,000 active members in more than 160 countries. This is the world's largest technical/professional society, dedicated to fostering technological innovation and excellence for the benefit of humanity. IEEE provides more than 3.5 million digital libraries and currently has organized about 1,300 annual conferences, worldwide.

IEEE Indonesia section, which is a part of IEEE global, has already been established for 28 years. It currently has about 1,395 active members, with activities in 6 society chapters, namely Computer Society Chapter, Communications Society Chapter, Circuits and Systems Chapter, Engineering in Medicine and Biology Chapter, Solid State Circuits Society Chapter, and Power and Energy Chapter. Moreover, IEEE Indonesia section also has 4 joint chapters, namely Joint chapter of Microwave Theory / Antennas \& Propagation, Joint chapter of Aerospace \& Electronics Systems Society / Geoscience \& Remote Sensing Society, Joint chapter of Control System Society / Robotics \& Automation Society, and Join Chapter of Education Society / Electron Devices Society / Power Electronics Society / Signal Processing Society.

IEEE Indonesia Section has 25 student branches in several universities in Java, Sumatera, Bali and Sulawesi islands and three Affinity Groups, namely Women in Engineering, SIGHT in Telemedicine, and SIGHT in Humanitarian Technology.

IEEE Indonesia section has organized several activities almost weekly. Its activities are related to Technical, Education, and Social Activities, such as ICT Training, Workshop, International Seminar, Focus Group discussion, and Distinguish Lecturer Tour (DLT) activities all around Indonesia. The main discussed topics are related to the technology for humanity, such as Internet of Things (IoT), Artificial Intelligent, Robotic technology, Biomedicine Technology, Antenna and Microwave, Circuit and Device, Renewable Energy, etc. Recently, IEEE Indonesia section organized two days 5G training; with the trainer is the one of the worldwide recognized professor in the field of Wireless Communication. We believed that it was the first 5G training activities in the Asia Pacific region.

In terms of collaboration, IEEE Indonesia section has a good and mutual relationship with ICT organizations, Industries, Universities as well as the government in Indonesia. IEEE Indonesia also participated in the preparation of forming a new regulation related to the ICT in Indonesia.

Through this opportunity, I would also like to highlight that Indonesia is an emerging country, one of the fastest growing countries in South East Asia and Pacific. Based on International Data Corporation, Indonesia has become the largest spender on ICT in South East Asia and is ranked 19th by spending globally. This is 
related to the Indonesia Economic Masterplan to 2025 (MP3EI) that Indonesia has ambitious plans and strategies to accelerate the economic development through ICT infrastructures.

As a critical hub to the Sub-Districts and Villages, the Palapa Ring Development Project connects 34 provinces and 440 cities/districts, stitching a circumference of 36,000 km fiber optics cable. The National Backbone Network, the Palapa Ring, will be completed with the last implementation in the submarine cable in the most eastern part, Papua Province. The National Network capacity and speed would be much improved with its completion. A network failure or disconnection in the Ring would be compensated by rerouting traffic through the other side.

However, the challenge is how to make these plans come into fruition and provide greater access to ICT beyond Jakarta and the Island. Palapa Ring connects Provinces and all Districts, as a critical hub to the SubDistricts and Villages. The capacity is practically unlimited (Tbps), cheaper access and better guarantee of continuity.

The Palapa Ring could easily provide Network Transit for Asia and Pacific Region, between the Indian and Pacific Oceans and the three (3) Continents (Asia-Australia-Americas). It would be easy to access our neighboring ASEAN countries, Singapore, Brunei Darussalam, Malaysia, Philippines, and Thailand.

The ICITACEE 2015 conference provides a forum for researchers, academicians, professionals, and students from various engineering fields and with cross-disciplinary working or interested in the development and design of information technology, computer system, and electrical engineering to interact and disseminate the latest issues and researches. It also offers opportunity to enjoy the heritage and the beauty of Semarang.

I do hope in the near future the event will be continued and strengthened, so the result will give more benefit and positive impact to the Indonesian people. Technology drives innovation, people can do more, do better. Technology drives higher quality of life, people can live better.

In this occasion, I would also like to say welcome to Semarang, one of the famous destinations in Indonesia. Semarang serves beautiful heritages, mountain and scenery with warm and friendly people, a vibrant culture and lifestyle.

Finally, we do hope all of you will have enjoyable and valuable experience. During this 3 days conference, you may share your best knowledge in your area of research and professional activities.

Thank you.

Semarang, 16 October 2015.

IEEE Indonesia Section Chair 


\section{2nd International Conference on Information Technology, Computer, and Electrical Engineering (ICITACEE)}

\section{Conference Committee}

General Chair : R. Rizal Isnanto (Universitas Diponegoro)

Co-Chair : Mochammad Facta (Universitas Diponegoro)

Secretary : Dania Eridani

\section{Organizing Committee:}

Munawar Agus Riyadi

Adian Fatchur Rochim

Rinta Kridalukmana

Oky Dwi Nurhayati

Kurniawan Teguh Martono

Eko Didik Widianto

Ike Pertiwi Windasari

Adnan Fauzi

Andi Widiasmoro

Okta Purnamasari

Melati Mawas Titi

\section{Steering Commitee:}

Hiroshi Ochi (Kyushu Institute of Technology, Jepang)

Hiroshi Furukawa (Kyushu University, Jepang)

Kuncoro Wastuwibowo (IEEE Indonesia Section)

Trio Adiono (IEEE Solid State Circuits Indonesian Chapter)

Heri Mauridhie (Sepuluh Nopember Institute of Technology)

Razali Ismail (University Teknologi Malaysia)

Taufik (California Polytechnic State, USA)

\section{Technical Program Committee:}

Wahyul Amien Syafei (Diponegoro University, Indonesia)

R. Rizal Isnanto (Diponegoro University, Indonesia)

Mochammad Facta (Diponegoro University, Indonesia)

Oky Dwi Nurhayati (Diponegoro University, Indonesia)

Munawar Agus Riyadi (Diponegoro University, Indonesia)

Aris Triwiyatno (Diponegoro University, Indonesia)

Hermawan (Diponegoro University, Indonesia)

Sidiq Syamsul Hidayat (Semarang State Polytechnics, Indonesia)

Trio Adiono (Bandung Institute of Technology, Indonesia)

Heri Mauridhie (Sepuluh Nopember Institute of Technology, Indonesia)

Masayuki Kurosaki (Kyushu University, Jepang)

Adhi Susanto (Gadjah Mada University, Indonesia)

Supari (Semarang University, Indonesia) 
Slamet Riyadi (Soegijapranoto Katholic University, Indonesia)

M. Hadin (Sultan Agung Islamic University, Indonesia)

Razali Ismail (University Teknologi Malaysia)

Taufik (California Polytechnic State, USA)

Hendra Setiawan (Indonesia Islam University, Indonesia)

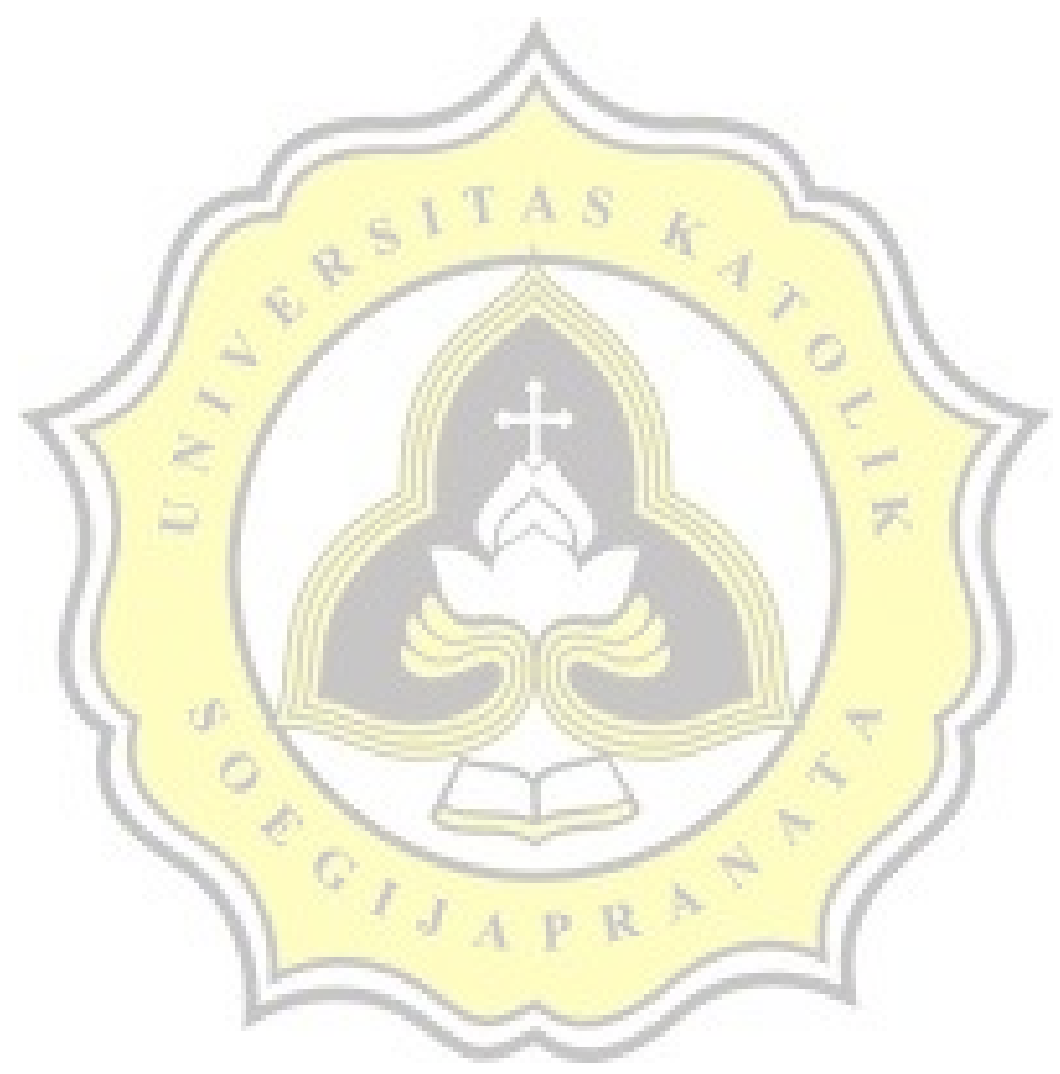




\section{TABLE OF CONTENTS}

\section{Keynote Speakers}

1 Novel Device Architectures and Carbon Based Materials for Future Nanoelectronics Razali Ismail

2 Distributed Consensus Control of Robot Swarm with Obstacle and Collision Avoidance Bambang Riyanto Trilaksono

3 Context-Awareness: Connecting Computing with Its Environment Lukito Edi Nugroho

\section{Information and Computer Technologies}

8 Exploring the Perception of Indonesian Students on Mendeley Reference Management Software in Academic Writing Muhammad Basri, Andi Anto Patak

17 Time Series Forecasting Using Exponential Smoothing (To Predict the Number of Visitor of the Website of Sebelas Maret University)

Rini Anggrainingsih, Gilang Romadhon Aprianto, Sari Widya Sihwi

23 Model of Human Resources for Health Information Systems Bens Pardamean, Timor Utama, Diah Rostanti Fadilah

29 CANREG 5 Networks for Indonesia Bens Pardamean, Teddy Suparyanto, Diah Rostanti Fadilah

34 Popular Games, Can Any Concept of Cognitive Preschoolers Be in It? Endah Sudarmilah, Adhi Susanto, Ridi Ferdiana, Neila Ramdhani

39 An Integrative Framework of COBIT and TOGAF for Designing IT Governance in Local Government Iis Hamsir Ayu Wahab, Assaf Arief

44 Fuzzy MADM for Major Selection At Senior High School Fata Nidaul Khasanah, Adhistya Erna Permanasari

49 Sentinel Web: Implementation of Laravel Framework in Web Based Temperature and Humidity Monitoring System Lathifah Alfat, Aris Triwiyatno, R. Rizal Isnanto

55 Impact of Service-Oriented Architecture Adoption in Information System Erick Fernando, Derist Touriano, Rico Rico

59 Crosscutting Concerns Refactoring in Agent Framework Maman Somantri, Lukito Edi Nugroho, Widywan Widyawan, Ahmad Ashari

66 Developing Agent Application Using Aspect Oriented Aglets Framework Maman Somantri, Lukito Edi Nugroho, Widywan Widyawan, Ahmad Ashari

71 Autoregressive Integrated Moving Average Modeling in the Financial Market Peihao LI, Chaoqun Jing, Tian Liang, Zhenglin Chen, Mingjia Liu, Li Guo

75 User Experience Model in the Interaction Between Children with Special Educational Needs and Learning Media Tri Sagirani, Lukito Edi Nugroho, Paulus Insap Santosa, Amitya Kumara

79 Performance Analysis of Edge and Detailed Preserved Speckle Noise Reduction Filters for Breast Ultrasound Images

Dina Arifatul Khusna, Hanung Adi Nugroho, Indah Soesanti

84 Virtual Sensor for Time Series Prediction of Hydrogen Safety Parameter in Degussa Sintering Furnace Dede Sutarya, Adhi Mahendra

90 Expert System Applications for Early Diagnosis Teeth and Oral Disease in Children Septya Maharani, Nataniel Dengen, Galih Yudha Saputra, Dyna Marisa Khairina, Heliza Rahmania Hatta 
95 Department Recommendations for Prospective Students Vocational High School of Information Technology with Naïve Bayes Method

Dyna Marisa Khirina, Fajar Ramadhani, Septya Maharani, Heliza Rahmania Hatta

100 Data Acquisition and Processing of Movement and Position for AUVs with Experiment Results Nanang Syahroni, Hari Wahjuningrat Suparno, Henggar Budiman, Choi Jae Weon, Yuniar Riska W.P., Metha Puspa I.

105 Feature Extraction for Classifying Lession's Shape of Breast Ultrasound Images Using Adaptive Median Filter

Hesti Khuzaimah Nurul Yusufiyah, Hanung Adi Nugroho, Teguh Baratha Adji, Anan Nugroho

110 The Role of Management Information System in Data Surveillance of Maternal and Child Health Kurniawan Teguh Martono, Yudhi Dharmawan

116 Stroke Identification System on the Mobile Based CT Scan Image Oky Dwi Nurhayati, Ike Pertiwi Windasari

120 Design of Management Information Systems Research, Publications and Community Service Kodrat Iman Satoto, Kurniawan Teguh Martono, R. Rizal Isnanto, Rinta Kridalukmana

126 Application of Liver Disease Detection Using Iridology with Back-Propagation Neural Network R. G. Alam Nusantara Putra Herlambang, R. Rizal Isnanto, Ajub Ajulian Z.

131 Geographics Information System of Islamic School in Cilacap Isti Qomariyah Kumala Dewi, Ike Pertiwi Windasari, Kodrat Iman Satoto

136 Portability Characteristic Evaluation Academic Information System Assessment Module Using AIS Quality Instrument

Umi Laili Yuhana, Istiningdyah Saptarini, Siti Rochimah

141 Generic Social Network Data Crawler Using Attributed Graph Rinta Kridalukmana

146 Statistical Methods Application in Comprehensive Sustainability Index and Its Application in Regional Sustainability Measurement

Peihao Li, Mingjia Liu

152 Study on the Correlation of Web Repository Ranking to the Green Campus Ranking of Indonesian Universities

Adian Fatchur Rochim, Riri Fitri Sari

157 Palmprint Recognition System Based on Principle-lines Feature Using Euclidean Distance and Neural Network

R. Rizal Isnanto, Ajub Ajulian Z., Eko Didik Widianto

163 Multiplying Cipher Images on Visual Cryptography with ElGamal Algorithm Alexander Edi Suranta Kacaribu, Ratnadewi Ratnadewi

167 Vowel Pronunciation in Indonesian Language Recognition Using the Lips Angle Measurement and Lips Area

Ratnadewi Ratnadewi, Adhi Fajar Sakti Wahyudi, Anisa Fardhani Prasetyaningtyas

173 Electromyography (EMG) Signal Compression using Sinusoidal Segmental Model Florentinus Budi Setiawan, Siswanto Siswanto

\section{Green Technology}

177 A Mobile Diabetes Educational System for Fasting Type-2 Diabetics in Saudi Arabia Mohammed Alotaibi

181 Review: Interoperability Model of eGoverment Services I Wayan Ordiyasa, Lukita Edi Nugroho, Paulus Insap Santosa, Ridi Ferdiana, Wahyudi Kumorotomo

187 Expert System for Campus Environment Indexing in Wireless Sensor Network Sumardi Sumardi, Oky Dwi Nurhayati, Muhammad Naufal Prasetyo, Eko Didik Widianto

191 Optimization of Photovoltaic Farm Under Partial Shading Effects Using Artificial Intelligent Based Matrix Switch Controller Antonius Rajagukguk, Dedet Candra Riawan, Mochamad Ashari

197 Implementation of Photovoltaic and Simple Resonant Power Converter for High Frequency Discharge Application Mochammad Facta, Hermawan Hermawan, Nngurah Ayu Ketut Umiati, Zainal Salam, Zolfakle Buntat 
201 Feature Extraction and Classification for Detection Malaria Parasites in Thin Blood Smear Hanung Adi Nugroho, Son Ali Akbar, E. Elsa Herdiana Murhandarwati

206 An Epileptic Signal Preictal Ictal Using PCA, K-Means, K Nearest Neighbors Siswandari Noertjahjani, Risanuri Hidayat, Samekto Wibowo, Adhi Susanto

\section{Electronics and Devices}

211 Two Phase Flow Imaging Using Infra Red Tomography Sallehuddin Ibrahim, Muhammad Abu Bakar Sidik, Mohd Amri Md Yunus

215 Design of Self Balancing Pitch Control in Fixed Wing Unmanned Aerial Vehicle with Fuzzy Logic Controller Aris Triwiyatno, Wahyul Amien Syafei, Teguh Prakoso, Budi Setiyono, Aristya Panggi Wijaya

220 Intensity Average Value of Image Segmentation for Infrared Image of Environmental Condition S.R. Sulistiyanti, M. Komarudin, L. Hakim, A. Yudamson

225 FPGA-Based System for Countinous Monitoring of Three Human’s Body Vital Signs Aminuddin Rizal, Munawar Agus Riyadi, Darjat Darjat

231 Robust Control Design for a Spindle of Lathe Machine Moh Khairudin

237 Smart Controller Design of Air to Fuel Ratio (AFR) and Brake Control System on Gasoline Engine Aris Triwiyatno, Enda Wista Sinuraya, Joga Dharma Setiawan, Suroto Munahar

243 Design of Prepaid Energy Meter Based on PROTEUS Heribertus Himawan, Catur Supriyanto, Adrin Thamrin

248 The Development of Track Record Application for Conservation Activity and Wildlife in Indonesia Arie Vatresia, Jonathan Sadler, Rendra Regen Rais

254 A High Speed Low Power Reading Scheme in DRAMs Using Resonant Tunneling Diode Ahmed Lutfi Elgreatly, Ahmed Ahmed Shaaban, El Sayed M. El-Rabie

260 Control System of Train Speed Based on Fuzzy Logic Controller Reza Dwi Utomo, Sumardi Sumardi, Eko Didik Widianto

266 Comparison Methods of Noise Elimination for Pregnancy Image Processing Moh Khairudin, D. Rahmawati

270 Maximum Power Point Tracking Simulation for a Photovoltaic System Susatyo Handoko, Tejo Sukmadi

275 Design of Multisensor IMU for Land Vehicle Wahyudi Wahyudi, Ngatelan Ngatelan

279 Numerical Design of Dual Resonant Phased Array RF Coil for MRI 3T and 7T System Basari Basari, Sri Yuliyanti, Eko Tjipto Rahardjo, Fitri Yuli Zulkifli

283 Property Investigation of Nanofiber Polyaniline as Active Material for Biosensor Ngurah Ayu Ketut Umiati, Mochammad Facta, Kuwat Triyana, Kamsul Abraha

288 The Depletion Influence on the Non-planar Vertical MOSFET Threshold Voltage Munawar Agus Riyadi, Darjat Darjat, Teguh Prakoso, Jatmiko E. Suseno

\section{Power Systems}

292 Reduction of Harmonic with LLCL Filter on Residential Loads 450 VA and 900 VA in Central Java, Indonesia Sapto Nisworo, Hamzah Berahim, Suharyanto Suharyanto, Tumiran Tumiran

298 A Three-phase Power Flow Analysis for Electrical Power Distribution System with Low Voltage Profile Lukmanul Hakim, Muhamad Wahidi, Umi Murdika, Federico Milano, Junji Kubokawa, Naoto Yorino

304 Design of Photovoltaic Powered Converter to Provide AC Controlled Voltage Source Slamet Riyadi

310 Smart Monitoring of Electrical Quantities Based on Single Board Computer BCM2835 Gigih Forda Nama, Dikpride Despa, Muhamad Komarudin, Mardiana Mardiana, Ady Kurniawan

316 Assessment of TRV Parameters and Overvoltages in Three-Phase Ungrounded Faults Alejandro Marmolejo, Mirko Palazzo 
322 The Comparative Study of Buck-Boost, Cuk, Sepic and Zeta Converters for Maximum Power Point Tracking Photovoltaic Using P-O Method Soedibyo Soedibyo, Budi Amri, Mochamad Ashari

328 Impact of High Penetration of Photovoltaic Generation on Voltage Fluctuation of Transmission and Distribution Systems Jimmy Trio Putra, Sarjiya Sarjiya, M. Isnaeni BS

332 Study on Surface Resistance of Epoxy Resin Filled Silicon Rubber and Silica Due to Electrical Tracking Abdul Syakur, Tumiran Tumiran, Hamzah Berahim, Rochmadi Rochmadi

336 Blackout Risk Assessment for IEEE 30 BUS System Muhammad Usman Cheema, Muhammad Usman Aslam, Adnan Bashir, Maria Komal, Naila Kousar Rao

342 Involving Generator Capability Curves in Optimal Power Flow Hermagasantos Zein, Yutra Sabri

347 Air Flow Numerical Simulation on Rotor-Stator Surface of Flux Axial Permanent Magnet Generator Prih Sumardjati Mulyaseputra, Sasongko Pramono Hadi, F. Danang Wijaya, Suharyanto Suharyanto

353 Harmonic Current Elimination in Industrial Power Systems Deria Pravitasari, Deria Pravitasari, Eka Firmansyah, T. Haryono

358 Interconnection of Hydro Power Plant through $20 \mathrm{kV}$ Distributed Line to Improve Electrical Power Supply in Dieng - Central Java Mochammad Facta, Hermawan Hermawan

362 Morphological Analysis of Epoxy Resin After Electrical Tracking Juningtijastuti Juningtijastuti, Abdul Syakur

\section{Telecommunications}

367 Energy Detector Threshold Under White Gaussian Noise Channel in Cognitive Radio System Nasrullah Armi, Chaeriah Bin Ali Wael, Muhammad Arshad, Dadin Mahmudin, Pamungkas Daud

371 Modeling and Simulation of OFDM Scheme for Radio Over Fiber (RoF) Fauza Khair, Fakhriy Hario P, I Wayan Mustika, Budi Setiyanto, Sevia Mahdaliza Idrus

377 Spectrum Sensing Performance in Cognitive Radio System Nasrullah Armi, Chaeriah Bin Ali Wael, Muhammad Arshad

381 Performance of AOMDV Routing Protocol Under Rushing and Flooding Attacks is Manet Sukiswo Sukiswo, Muhamad Rifqi Rifquddin

386 SDN Based Data Center Designs Using Cisco ACI Architectures Atif Khan

392 Multi-Objective Cuckoo Search Algorithm for Task Scheduling in the Cloud Environments Farnaz Sharifi Milani, Nima Jafari Navimipour

397 Investigation and Comparison of Expert Cloud and E-learning Systems Nima Jafari Nanimipour, Batool Zareie

402 Cooperative Fair Multichannel MAC Protocol for Cognitive Radio Ad Hoc Network Aghus Sofwan, Salman A. AlQahtani

408 Adaptive Blind Equalization for Differential SC-FDMA System Ziyan Jia, Ming Wu, Lianfeng Shen

412 Implementation of K-Best Method for MIMO Decoder in WLAN 802.11n Wahyul Amien Syafei

417 Basic Study of Multiple Symbol Differential Detection for SC-FDMA System Ziyan Jia, Qiuye Li, Lin Shen

421 Performance Analysis of Transceiver 4 x 4 Space Time Block Coded MIMO-OFDM System Subuh Pramono, Tommi Hariyadi, Budi Basuki Subagio

425 Implementation of Detection Device Method on Seamless Proxy Mobile Internet Protocol Version 6 (SPMIPv6) Wiwik Wiharti, Ihsan Lumasa Rimra, Rikki Vitria, Igor Novid

429 Managing Bandwidth Resource for Vehicular Ad-hoc Networks Sami S. Alwakeel, Agung B. Prasetijo 
433 Measurement System of Temperature, Humidity and Air Pressure Over 433 MHz Radio Frequency. an Application on Quadrotor

Budi Setiyono, Sumardi Sumardi, Rafdito Harisuryo

437 TMS: Traffic Management System in VANETs

Jetendra Joshi, Manash Jyoti Deka

444 HoMeTrack: RFID-based Localization for Hospital Medicine Tracking System Kurnianingsih Kurnianingsih, Muhammad Anif, Helmy Helmy, Anton Satria Prabuwono

449 Ontology-based Context Aware for Ubiquitous Home Care for Elderly People Kurnianingsih Kurnianingsih, Lukito Edi Nugroho, Widyawan Widyawan, Lutfan Lazuardi, Khamla Nonalinsavath

455 Simulation of Attendance Application on Campus Based on RFID (Radio Frequency Identifiation) Dania Eridani, Eko Didik Widianto

459 A Comparative Analysis and Survey of Handoff for VoIP Applications in Mobile IPv6 Protocols Wiwik Wiharti, Ihsan Lumasa Rimra, Efrizon Efrizon, Igor Novid

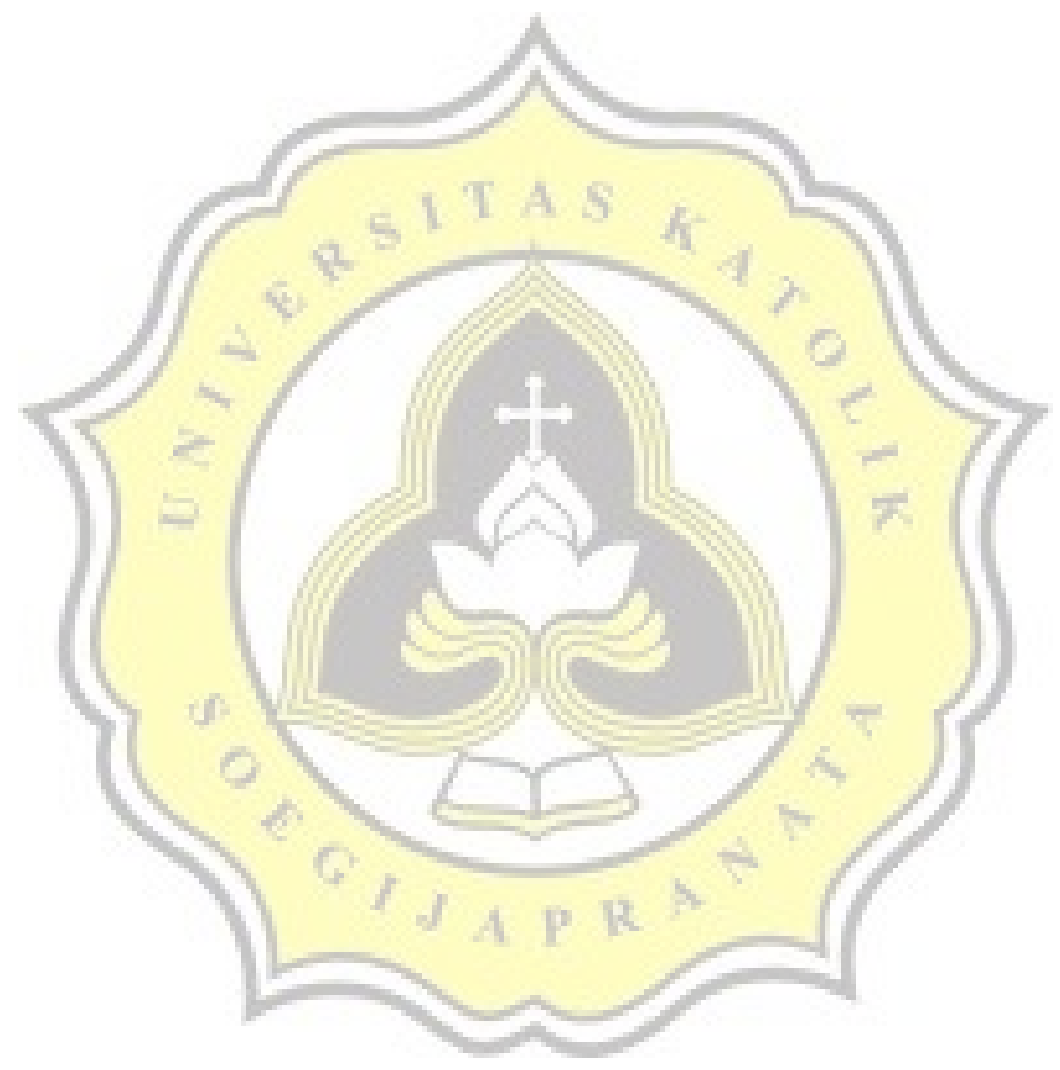




\title{
Design of Photovoltaic Powered Converter to Provide AC Controlled Voltage Source
}

\author{
Slamet Riyadi \\ Dept. of Electrical Engineering \\ Soegijapranata Catholic University \\ Semarang, Indonesia \\ s_riyadi672003@yahoo.com
}

\begin{abstract}
Stand-alone photovoltaic systems are still required in locations where electricity is unavailable. They can provide electric energy for pumping systems, lightings, etc. This paper presents a design of a photovoltaic powered converter to provide regulated AC voltage. The system consists of a buck chopper and an inverter. The chopper acts as a Maximum Power Point Tracker to optimize the battery charging. The inverter used in the proposed system is operated as a controlled voltage source to force its output voltage tracks the reference. The controllers are implemented by dsPICs. Simulation and experimental results show the effectiveness of the proposed system with simple control scheme. Sinusoidal voltage can be generated by the inverter based on look-up table method. The power equilibrium is also achieved.
\end{abstract}

Keywords-photovoltaic; controlled voltage source; inverter; MPPT; power equilibrium

\section{INTRODUCTION}

Photovoltaic (PV) based electric energy is very important due to the fossil energy crisis and is free from environmental pollution. PV modules need solar energy to produce electric energy in DC quantity. Due to the availability of the solar energy, PV modules must be operated in their maximum power point so the maximum power point tracker (MPPT) is required. There are many method used in MPPT control techniques [1].

The PV systems may be grid-integration or stand-alone systems. The first systems are connected to existed grid for certain purposes. They are functioned to transmit electric energy generated by PV modules to the grid. They sometimes have capability to reduce harmonics [2]-[3]. While the second systems are commonly installed in the remote area with/without batteries.

Most applications of the stand-alone PV systems are focused on water pumping systems. A general PV powered water pumping system consisted of PV, DC-DC converter, inverter and induction motor was designed and simulated by using SIMULINK [4]. Another system using boost chopper as a MPPT was also simulated by using MATLAB [5]. The DC-DC stage can also be implemented by current-fed inverter and voltage-doubler rectifier [6] or by a push-pull inverter, high frequency transformer and rectifier [7] to increase the system performance. By using PV modules and boost MPPT to drive DC motor coupled water pump, a simpler system can be designed [8]. To reduce the system costs, battery-less system has been designed [9].

Commonly, the designed systems have no feedback control on $\mathrm{AC}$ voltage so when the loads change the $\mathrm{AC}$ voltage will also varies. The stand-alone PV system with regulated AC voltage is presented in this paper. The proposed system consists of two stage converters, the first one is buck chopper functioned as a MPPT and the second one is a single-phase inverter operated as an $\mathrm{AC}$ controlled voltage source.

\section{THE PROPOSED SYSTEM}

The proposed system consisted of PV modules, a buck-type MPPT, batteries, a single-phase inverter and AC loads is depicted in Fig. 1. Electric power generated by PV modules will be forced at its maximum power point by the MPPT. The output power of the MPPT is used to charge the batteries and supply the AC loads via an inverter under a certain condition (under sufficient irradiance). For a critical condition, the AC loads will be supported by the sum of power from PV modules and the batteries.

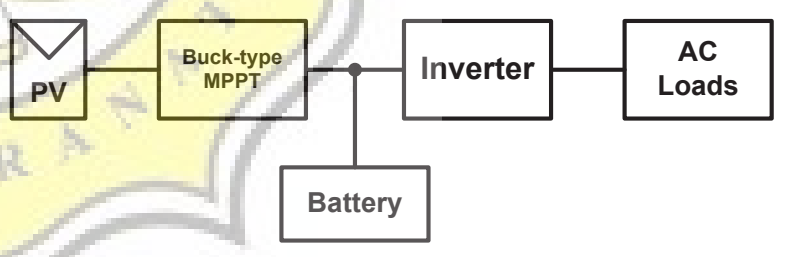

Fig. 1. Block of the proposed system

\section{A. PV Modules and Buck-type MPPT}

A PV module can be used to convert solar energy into electric energy. For its characteristic looks like a combination of current source and voltage source, a PV module must be operated at a point that generates highest power at certain irradiance, it is named maximum power point. Operation under this condition, the PV module produces current $I_{M P P}$ at its voltage $V_{M P P}$ so the maximum power $P_{M P P}$ can be stated as

$$
P_{M P P}=V_{M P P} \cdot I_{M P P}
$$


Direct connecting a PV module to certain load $\left(R_{L}\right)$ results in current flowing from the PV module $I_{P V}$ at its terminal voltage $V_{P V}$, where

$$
R_{L}=\frac{V_{P V}}{I_{P V}}
$$

The power generated will be maximum only if

$$
R_{L}=R_{M P P}=\frac{V_{M P P}}{I_{M P P}}
$$

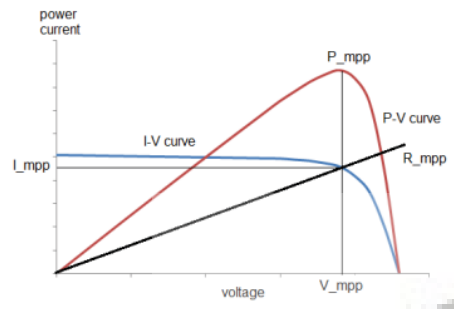

Fig. 2. Characteristic curve of a photovoltaic cell

This value is too difficult to be achieved because $I_{M P P}$ and $V_{M P P}$ will vary according to solar irradiance. So this can be concluded that connecting loads directly to PV modules will produce power less than $P_{M P P \text {. }}$
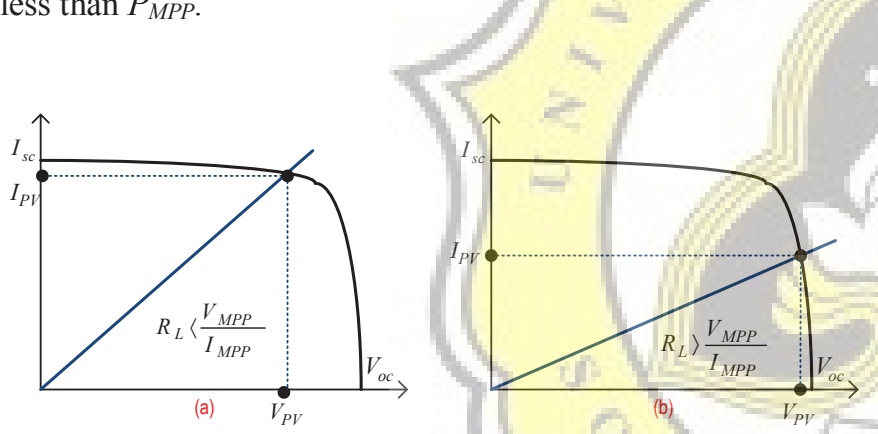

Fig. 3. Load line of direct connecting PV modules to loads

For the load resistance less than $R_{M P P}$, a buck-type MPPT can be inserted between PV modules and the load. This MPPT is implemented by a buck chopper which is operated to make the PV modules see the load resistance $R_{L}$ always equals to $R_{M P P}$. The relationship of input voltage $E$, output voltage $V_{o}$ and duty cycle $d$ of a buck chopper can be expressed as

$$
V_{o}=d . E
$$

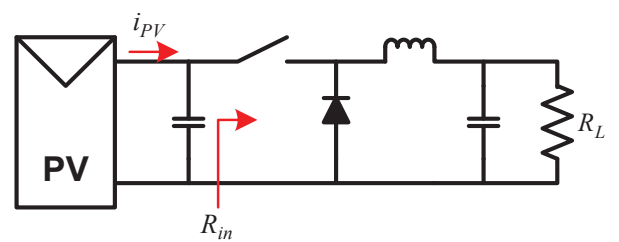

Fig. 4. A buck chopper as the core of MPPT
Due to the power equilibrium, the input power and output power of a chopper under ideal condition are the same, expressed as the following

$$
\begin{aligned}
& E . I_{\text {in }}=V_{o} \cdot I_{o} \\
& E . \frac{E}{R_{\text {in }}}=V_{o} \cdot \frac{V_{o}}{R_{L}}
\end{aligned}
$$

where $R_{\text {in }}, I_{\text {in }}$ and $I_{o}$ are the equivalent input resistance, input current and output current of a buck chopper, so that

$$
\begin{aligned}
& \frac{E^{2}}{R_{\text {in }}}=\frac{V_{o}^{2}}{R_{L}} \\
& R_{\text {in }}=\left(\frac{E}{V_{o}}\right)^{2} R_{L}=\left(\frac{1}{d}\right)^{2} R_{L}
\end{aligned}
$$

The comparison between $R_{L}$ and $R_{i n}$ will vary from $0(d=0)$ to unity $(d=1)$

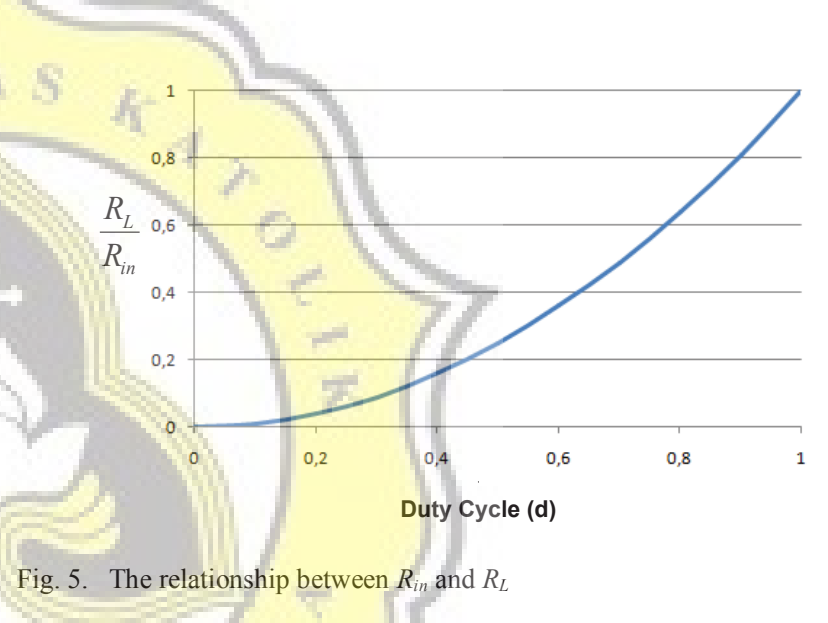

Connecting PV modules to the input side of the MPPT and a load to the output side will result in an equation under maximum power point as the following

$$
\text { 17. 17. } R_{\text {in }}=\frac{V_{M P P}}{I_{M P P}}=R_{M P P}
$$

By Substituting (6) into (5)

$$
\begin{aligned}
& R_{M P P}=\left(\frac{1}{d}\right)^{2} R_{L} \\
& d=\sqrt{\frac{R_{L}}{R_{M P P}}}
\end{aligned}
$$

For $d \leq 1$ then Eq.(7) is valid for

$$
\frac{R_{L}}{R_{M P P}} \leq 1 \text { then } R_{L} \leq R_{M P P}
$$

By varying the value of $d$ then $R_{i n}$ can be made equal to $R_{M P P}$ and the operation point of the PV modules is on its MPP. 


\section{B. Battery and Single-Phase Inverter as Controlled Voltage Source}

In the proposed system, PV-MPPT block was connected to batteries and a single-phase inverter to supply AC loads. Regardless the power losses of the MPPT, the input power $\left(P_{\text {in_ } \_}\right)$and output power $\left(P_{\text {out } \_} M\right)$ of the MPPT can be written as

$$
P_{\text {in_M }}=P_{\text {out } \_} M
$$

When the MPPT output power is expressed by multiplication of duty cycle, PV modules voltage and MPPT output current $I_{\text {out }} M$ , then

$$
\begin{aligned}
& V_{M P P} \cdot I_{M P P}=d \cdot V_{M P P} \cdot I_{\text {out_M }} \\
& I_{\text {out_M }}=\frac{I_{M P P}}{d}
\end{aligned}
$$

For the MPPT is parallel connected to the batteries and the inverter, so the relationship of battery current $I_{b a t}$ and inverter input current $I_{i n v}$ are stated as

$$
I_{\text {out_M }}=I_{\text {bat }}+I_{\text {inv }}
$$

If the batteries can be modeled as a series connection of an internal voltage $E$ and an internal resistance $r_{b a t}$ then the batteries terminal voltage $V_{T}$ is stated as

$$
\begin{aligned}
& V_{T_{-} b a t}=I_{b a t} \cdot r_{b a t}+E_{b a t} \\
& I_{b a t}=\frac{V_{T_{-} b a t}-E_{b a t}}{r_{b a t}}
\end{aligned}
$$

Here $\quad V_{T_{-} \text {bat }}=V_{\text {out_ }} M=V_{d c-\text { link }}\left(V_{d c-\text { link }}\right.$ is the inverter input voltage).

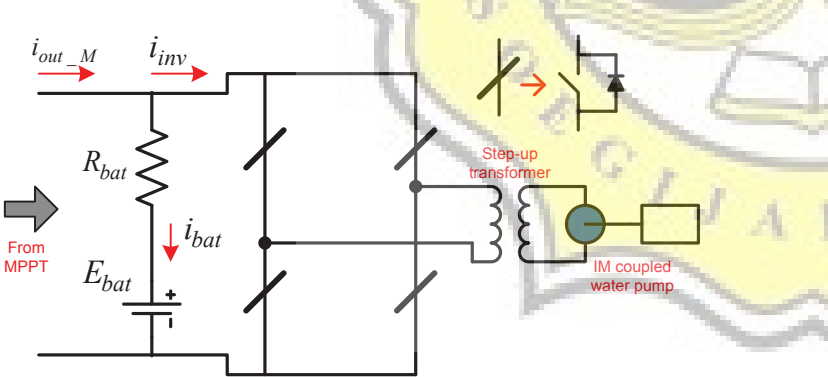

Fig. 6. Parallel connection of PV-MPPT with batteries and an inverter

Power equilibrium at dc-link of the inverter can be achieved if the sum of power absorbed by the battery $P_{b a t}$ and power delivered to the inverter $P_{i n v}$ equals to the PV modules power $P_{M P P}$, written as

$$
\begin{aligned}
& P_{M P P}=P_{b a t}+P_{i n v} \\
& P_{M P P}=V_{d c-l i n k} \cdot\left(I_{b a t}+I_{i n v}\right)
\end{aligned}
$$

Under normal condition, the inverter must be able to transfer power required by the AC loads. The proposed inverter is operated by Sinusoidal Pulse Width Modulation (SPWM). If the power losses of the inverter are neglected, then power relationship of the inverter input power $P_{i n v}$ and output power $P_{a c}$ is expressed as

$$
\begin{aligned}
& P_{i n v}=P_{a c} \\
& V_{d c-\text { link }} \cdot I_{i n v}=V_{a c} \cdot I_{a c} \cos \varphi
\end{aligned}
$$

where $V_{a c}, I_{a c}$ and $\varphi$ are RMS value of fundamental component of the inverter output voltage, RMS value of the inverter output current and phase angle between them. When a step-up transformer is used to supply the $\mathrm{AC}$ loads, so equations associated with apparent power of the inverter output $S_{a c}$ and the AC loads $S_{L}$ can be derived

$$
\begin{aligned}
& S_{a c}=S_{L} \\
& V_{a c} \cdot I_{a c}=V_{L} \cdot I_{L}
\end{aligned}
$$

Finally

$$
I_{L}=\frac{N_{p}}{N_{s}} \cdot I_{a c}
$$

where $V_{L}, I_{L}, N_{p}$ and $N_{s}$ are RMS value of fundamental component of the AC loads voltage, RMS value of the AC loads current, the number of primary winding and the number of secondary winding of the step-up transformer.

\section{The Control Scheme of the Proposed System}

The proposed system has two control blocks, the first one is for the MPPT and the second is for the inverter. The MPPT controller requires detections of the PV modules voltage and current. The Perturb and Observe (P\&O) concept is applied to the proposed system by using 16-bit Digital Signal Controller (DSC) implemented by dsPIC30f4012. The high speed ADC of this dsPIC and its PLL facility give the accuracy of the controller. The basic concept of the MPPT controller is how to make the power of the PV modules maximum at any condition. This is done by detecting PV current and voltage and force the multiplication of both quantities will be maximum. The movement of the operating point of the MPPT is controlled by varying duty cycle. The flowchart of this control scheme is shown in Fig.8.

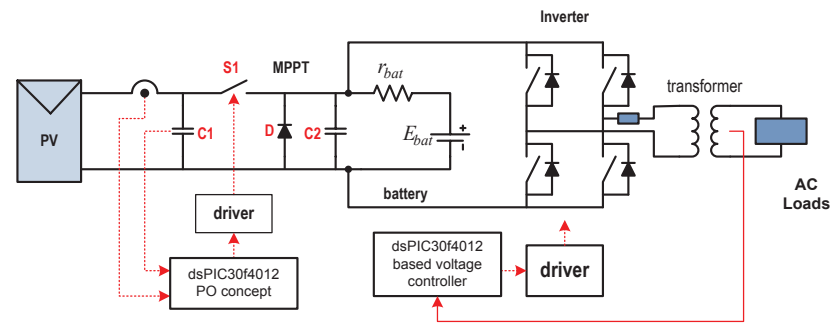

Fig. 7. The control scheme of the system 
The second converter is a single-phase inverter used to convert DC voltage into AC voltage with controllable magnitude (AC controlled voltage source). It must be capable to provide sinusoidal voltage with certain frequency and magnitude. The control scheme requires a template as a reference. The DSC has capability to provide look-up table facility. By using the numbers represents sinusoidal waveform, a sinusoidal based look-up table can be made. In every sampling process, the content of the look-up table component address will be taken. This will be compared to the actual voltage to get error. The flowchart of the controlled voltage source is depicted in Fig.9.

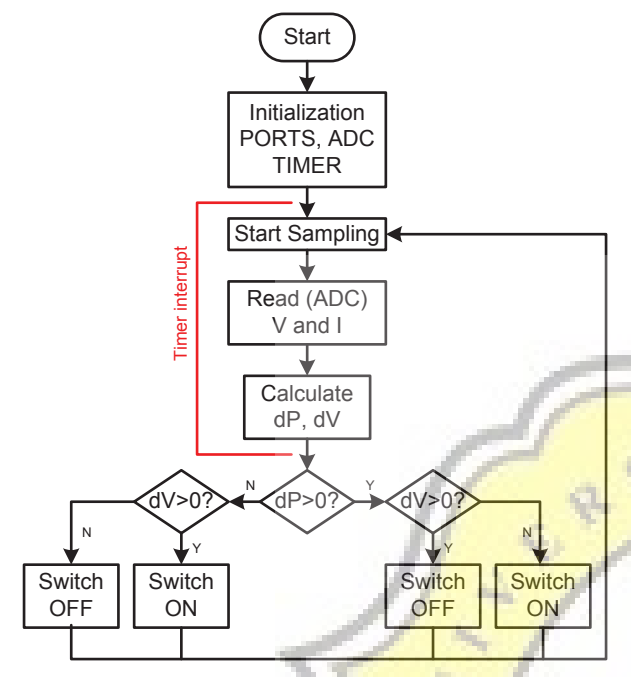

Fig. 8. Flowchart of the MPPT controller

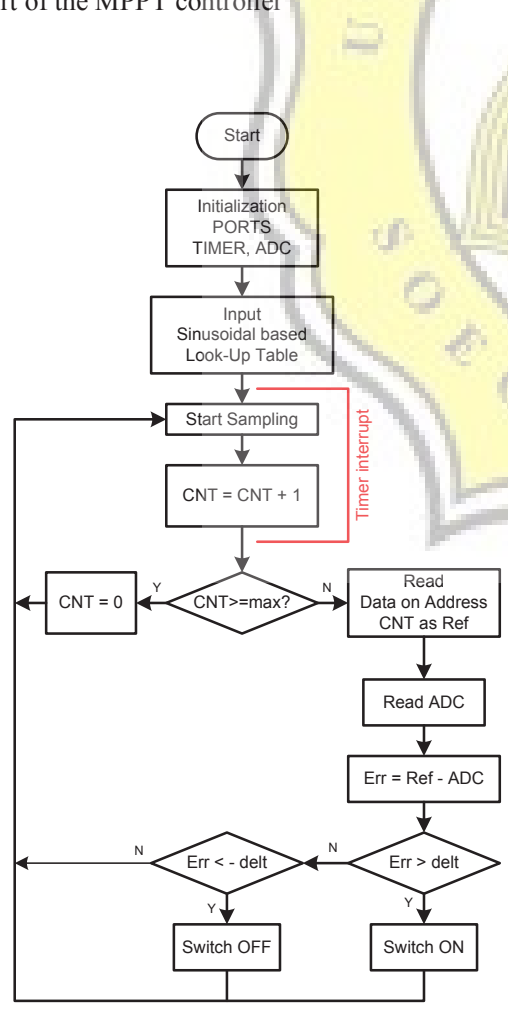

Fig. 9. Flowchart of the inverter controller

\section{RESULTS AND DISCUSSION}

Due to the above analysis, computer simulations using PSIM were done. Simulations were based on the circuit depicted in Fig. 7 with parameters shown in Table I. By using digital control in C-Block PSIM, the MPPT can make the PV modules generated power near their maximum power (Fig.10a). For the MPPT is a buck type, the MPPT output voltage is less than the PV modules voltage (Fig.10b). Tracking process is done by varying the duty cycle, it can be seen by investigating whether the switch is ON or OFF. This will influence the PV modules current (Fig.11).

TABLE I. SIMULATION PARAMETERS

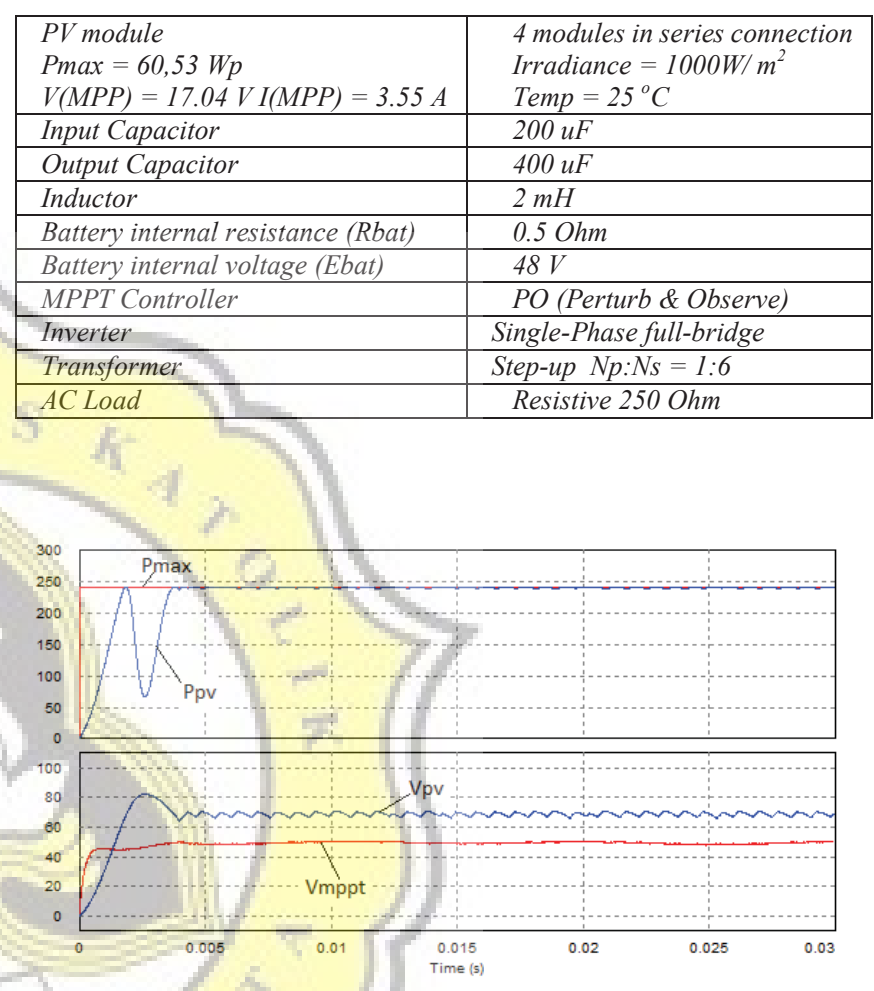

Fig. 10. Simulation results (a) maximum power and instantaneous power of the PV modules (b) the PV modules voltage and the MPPT output voltage

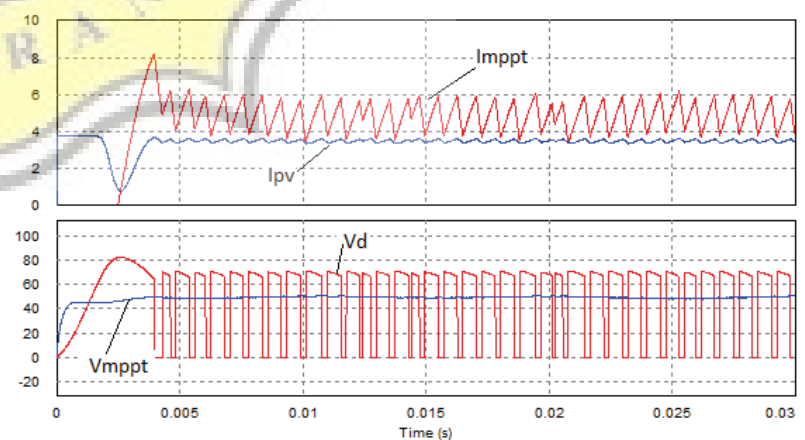

Fig. 11. Simulation results (a) the PV modules current and the MPPT output current (b) the MPPT output voltage and freewheeling diode voltage

To investigate power relationship, simulations with different irradiance were made. When the irradiance $1000 \mathrm{~W} / \mathrm{m}^{2}$ was 
taken, the PV modules generates power greater than the $\mathrm{AC}$ loads. The batteries absorb power from MPPT, this is shown by the power curve with positive value (Fig.12). Using the irradiance $500 \mathrm{~W} / \mathrm{m}^{2}$, power generated by the PV modules decreases until some points less than the AC loads. At these points, the batteries will discharge. It can be seen that the power curve of the batteries has negative value (Fig.13). The inverter operated as an AC controlled voltage source is capable to produce output voltage which tracks the reference (Fig.14).

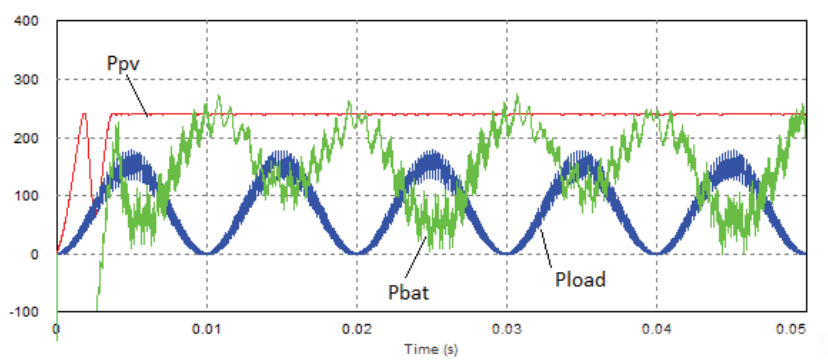

Fig. 12. Simulation results under irradiance $1000 \mathrm{~W} / \mathrm{m}^{2}$ for power generated by the PV modules $\left(P_{P V}\right)$, power absorbed by the battery $\left(P_{b a t}\right)$ and power delivered to the $\mathrm{AC}$ loads $\left(P_{\text {load }}\right)$

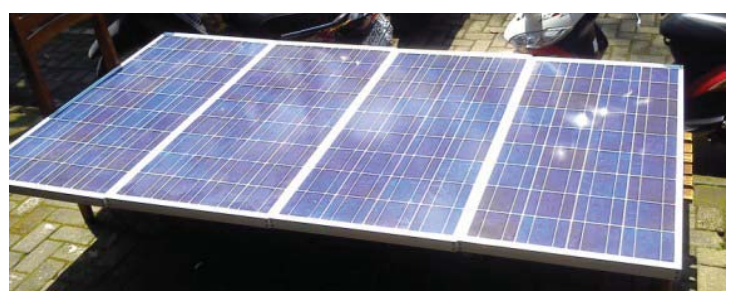

Fig. 15. PV modules used in experimental works

The PV modules voltage and current will change at every switching process (Fig.17 and Fig.18). The relationship of the PV modules voltage as the input voltage of the MPPT and its output voltage can also be seen. The voltage on the AC loads can be investigated by measuring the output voltage of the voltage transducer LEM LV 25-P. The voltage transducer must be set to provide values under 5 Volt due to the ADC of the DSC. Direct measurement of the voltage and current on AC loads is shown in Fig. 19.

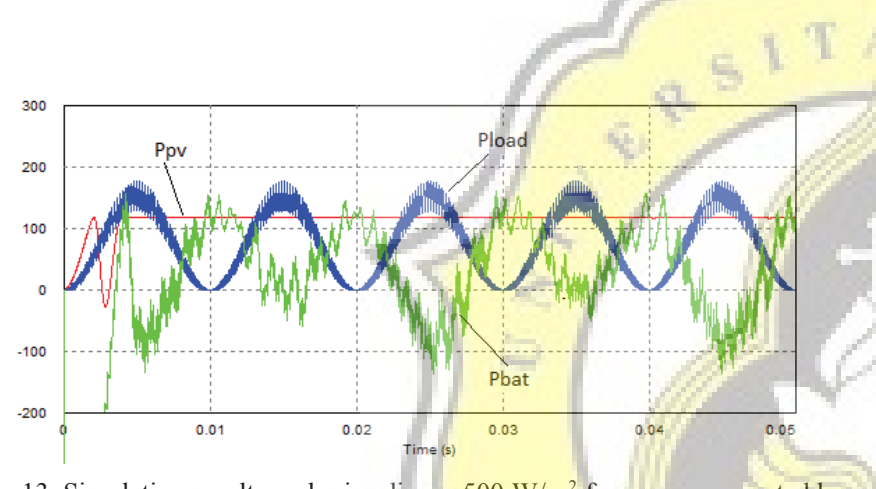

Fig. 13. Simulation results under irradiance $500 \mathrm{~W} / \mathrm{m}^{2}$ for power generated by the PV modules $\left(P_{P V}\right)$, power absorbed by the battery $\left(P_{b a t}\right)$ and power delivered to the AC loads $\left(P_{\text {load }}\right)$

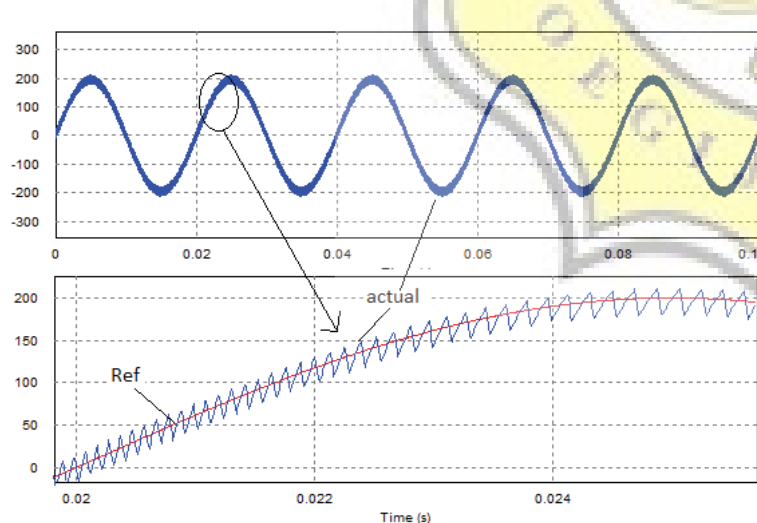

Fig. 14. Simulation result shows that the load voltage tracks the reference

Finally, the laboratory experiments were completed to verify the simulation works. Four PV modules were used generate electric power.

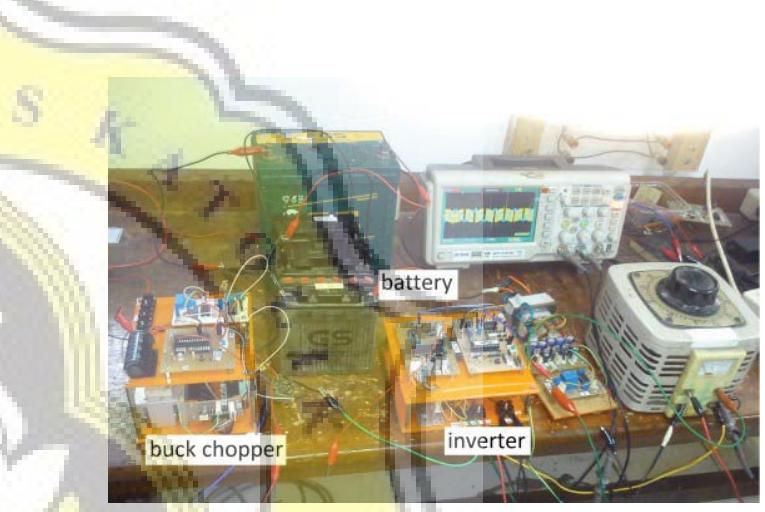

Fig. 16. Prototype of the proposed system

TABLE II. EXPERIMENTAL PARAMETERS OF THE PV MOdULE

\begin{tabular}{|c|c|}
\hline Max Power $($ Wp $)$ & $85 \mathrm{~W}$ \\
\hline Open Circuit Voltage $\left(V_{-} o c\right)$ & $21,6 \mathrm{~V}$ \\
\hline Short Circuit Current $\left(I_{-} s c\right)$ & $5,15 \mathrm{~A}$ \\
\hline Max Power Voltage $\left(V \_m p p\right)$ & $17,3 \mathrm{~V}$ \\
\hline Max Power Voltage $\left(I_{-}\right.$mpp $)$ & $4,63 \mathrm{~A}$ \\
\hline
\end{tabular}

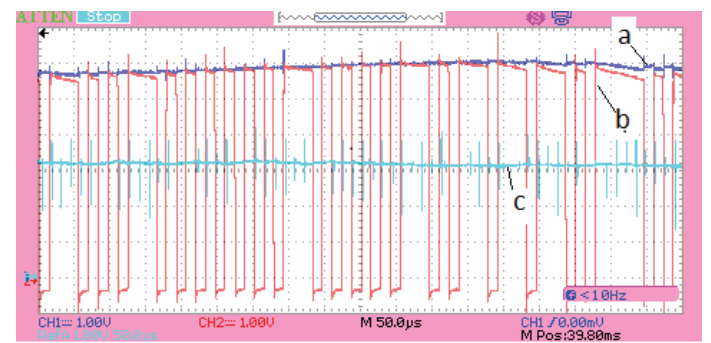

Fig. 17. Experimental results (a) PV modules voltage (b) voltage on freewheeling diode of the MPPT (c) the MPPT output voltage [scale 10V/div] 


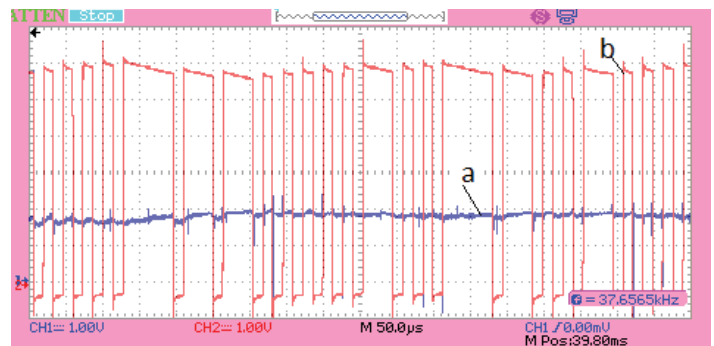

Fig. 18. Experimental results (a) PV modules current [scale 3A/div] (b) voltage on freewheeling diode of the MPPT [scale $10 \mathrm{~V} / \mathrm{div}$ ]

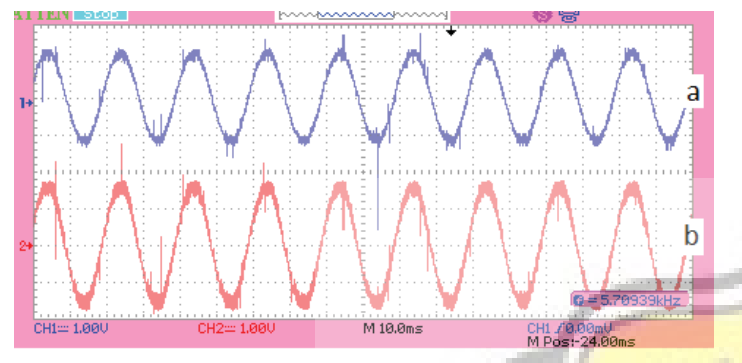

Fig. 19. Voltage and current of the AC loads directly measured (a) voltage [scale $300 \mathrm{~V} / \mathrm{div}]$ (b) current $[0.5 \mathrm{~A} / \mathrm{div}]$

\section{CONCLUSION}

A system consisted of PV powered converter with dual stage has been presented. The first stage implemented by a buck chopper as the MPPT has capability to force PV modules generate maximum power. This is controlled by using $\mathrm{P} \& \mathrm{O}$ concept applied to the 16-bit dsPIC. The dsPIC based controller with feedback signal taken from the AC load voltage can operate a single phase inverter as the second stage able to produce regulated $\mathrm{AC}$ power. The proposed system has better performance for the output voltage is regulated. Implementation the system to any loads can deliver the required rating of power.

\section{ACKNOWLEDGMENT}

This work was supported by The Directorate General of Higher Education, The Ministry of National Education, Republic of Indonesia.

\section{REFERENCES}

[1] T. Esram and P.L. Chapman, "Comparison of Photovoltaic Array Maximum Power Point Tracking Techniques", IEEE Transc. on Energy Conversion, vol.2, no.2, pp.439-449, June 2007.

[2] T. F. Wu, et al., "A Single-Phase Inverter System for PV Power Injection and Active Power Filtering With Nonlinear Inductor Consideration", IEEE Trans.on Industry Application, Vol.41, No.4, pp.1075-1083, Jul/August. 2005.

[3] D. C. Martins and K. C. A. de Souza, " A Single-Phase Grid-Connected PV System With Active Power Filter", International Journal of Circuits, Systems and Signal Processing, Vol.2, No.1, pp.50-55, 2008.

[4] T. Lajnef, S. Abid and A. Ammous, "Design and Simulation of Photovoltaic Water Pumping System", International Journal of Engineering and Advanced Technology, vol.2, no.4, April 2013.

[5] N. Chandrasekaran and K. Thyagarajah, "Modeling and Performance Study of Single Phase Induction Motor in PV Fed Pumping System using MATLAB", International Journal of Electrical Engineering, vol.5, no.3, pp. 305-316, 2012.

[6] J.V.M. Caracas, G.C. Farias, L.F.M. Teixeira and L.A.S. Ribeiro, "Implementation of a High-Efficiency, High-Lifetime, and Low-Cost Converter for an Autonomous Photovoltaic Water Pumping System", IEEE Transc. on Industry Applications, vol.50, no.1, pp.631-641, Jan/Feb 2014.

[7] K.V.B. Reddy and G.V.S.K. Rao, "Experimental Results of Photovoltaic Powered Induction Motor Drive for Pumping", Advance in Electronic and Electric Engineering, vol.3, no.2, pp.193-204, 2013

[8] A. Daoud and A. Midoun, "Single Sensor Based Photovoltaic Maximum Power Point Tracking Technique for Solar Water Pumping System", Electrical Power Quality and Utilisation, Journal Vol. XIV, No. 2, 2008.

[9] M.A. Vitorino, M.B.R. Corrêa, C.B. Jacobina and A.M.N. Lima, "An Effective Induction Motor Control for Photovoltaic Pumping", IEEE Transc. on Industry Electronics, vol.58, no.4, pp.1162-1170, April 2011. 